\title{
Differential effects of ginkgol C17:1 on cisplatin-induced cytotoxicity: Protecting human normal L02 hepatocytes versus sensitizing human hepatoma HepG2 cells
}

\author{
YUEYING LI ${ }^{1}$, XINCHI ZHANG ${ }^{2}$, XIAOMING YANG ${ }^{3}$, JUN LIU $^{4}$, \\ LINJIE LI ${ }^{5}$, WENBIN MA ${ }^{5}$ and MIN CHEN ${ }^{1}$ \\ Departments of ${ }^{1}$ Physiology and ${ }^{2}$ Immunology, School of Medicine; ${ }^{3}$ Department of Food Science and Engineering, \\ School of Food and Biological Engineering; ${ }^{4}$ Department of Biology, Institute of Life Science; \\ ${ }^{5}$ School of Medicine, Jiangsu University, Zhenjiang, Jiangsu 212013, P.R. China
}

Received April 5, 2018; Accepted December 18, 2018

DOI: $10.3892 /$ ol.2019.9974

\begin{abstract}
Liver cancer is a major healthcare problem and one of the leading causes of cancer-associated mortality in the world. To date, chemotherapy remains a common method for treating cancer and cisplatin is one of the most widely used chemotherapeutics. However, owing to drug resistance and side effects, it is imperative to identify a novel approach to improve the anticancer effect of cisplatin. Auxiliary chemotherapy drugs with minor toxicity to normal cells may represent a novel strategy for cancer therapy. Previous studies have indicated that ginkgol C17:1 exhibits anticancer effects in liver cancer cells in vitro and in vivo. The antitumor activity of ginkgol C17:1 has been reported in combination with cisplatin in human liver cancer cells. Owing to the route of systemic administration, liver cancer cells and normal hepatocytes were exposed to chemotherapeutics and auxiliary chemotherapy drugs. However, the effects of ginkgol C17:1 in normal hepatocytes remain unclear. In the present study, the biological effects of ginkgol C17:1 alone and as co-treatment with cisplatin were compared in human hepatoma cells and normal hepatocytes. Consistently, the results confirmed that in human hepatoma HepG2 cells, ginkgol C17:1 or cisplatin alone induced autophagy and apoptosis. The co-treatment increased cisplatin-induced apoptosis and inhibited cisplatin-induced autophagy. In comparison, the treatments in human normal L02 hepatocytes indicated that ginkgol C17:1 alone induced autophagy, whereas cisplatin alone induced apoptosis. The co-treatment inhibited cisplatin-induced apoptosis, but enhanced autophagy in L02 cells. Further investigation revealed that the AMP-activated
\end{abstract}

Correspondence to: Dr Min Chen, Department of Physiology, School of Medicine, Jiangsu University, 301 Xuefu Road, Zhenjiang, Jiangsu 212013, P.R. China

E-mail: chenmina88@yahoo.com

Key words: ginkgol C17:1, HepG2 cells, L02 cells, cisplatin, co-treatment protein kinase/serine/threonine protein kinase ULK1 and phosphoinositide 3-kinase/protein kinase B/mammalian target of rapamycin signaling pathways were involved in the underlying regulatory mechanisms. Taken together, the results of the present study provide the first evidence that ginkgol C17:1 protects normal hepatocytes against cisplatin-induced cytotoxicity while potentiating the anticancer effect of cisplatin chemotherapy. The differential effects on normal and cancer cells suggest that ginkgol C17:1 is a promising candidate for auxiliary chemotherapy.

\section{Introduction}

Liver cancer is a major worldwide healthcare problem, and one of the leading causes of cancer-associated mortality globally (1-3). For the majority of patients with advanced cancer, chemotherapy is accompanied by surgery, but the long-term prognosis of patients with liver cancer is poor (4). Cisplatin is one of the most useful anticancer agents available for cancer therapy, with the major pharmacological effect of inducing apoptosis in cancer cells (5). The success of cisplatin in anticancer treatment has triggered a search for additional, platinum $(\mathrm{Pt})$-based metal complexes with improved anticancer properties (6). However, severe side effects, including drug resistance, nephrotoxicity and gastrointestinal toxicity, have limited the curative effect of Pt-based complexes (7). Over the last decade, a new trend in cancer therapy has emerged from non-inferiority clinical trials testing combinations of chemotherapy agents with other ancillary medicine. For example, a combined treatment of cisplatin with gemcitabine has proven to be the preferred first-line therapy for patients with metastatic triple-negative breast cancer (8). Similarly, combinations of cisplatin with other ancillary medicine may be beneficial in liver cancer therapy. Therefore, the rational design and synthesis of potent small-molecule drugs, particularly plant extracts with low toxicity, may enhance the anticancer efficacy of cisplatin.

Apoptosis, known as programmed cell death, in which pro-apoptotic B-cell lymphoma 2 (Bcl-2)-associated X protein (Bax), cleaved caspase-3 and anti-apoptotic apoptosis regulator 
Bcl-2 are commonly used as markers, is accepted as the principal cellular mechanism contributing to the chemotherapeutic effects of anticancer drugs, including cisplatin, and is thus associated with the progression of cancer and the therapy of cancer cells (6). Another biological process, autophagy, which serves an essential role in cell development, tissue homeostasis and disease, is considered to exhibit positive and negative effects in the initiation, development and metastasis of cancer and is therefore of particular importance in this area $(9,10)$. Autophagy is thought to prevent cancer development in non-cancerous cells; however, once cancer has developed, autophagy facilitates tumor cell survival and proliferation, and protects tumor cells against stress as an adaptive response (11-13). Beclin-1 (a putative tumor suppressor), microtubule-associated protein 1 light chain 3 (LC3)I/II and adaptor sequestosome 1 (SQSTM1; p62) commonly serve as biomarkers in autophagy $(10,11)$.

Studies have revealed that interactions among components of apoptosis and autophagy form a complex signaling network, which is often induced by similar stimuli $(14,15)$. In mammalian cells, the phosphoinositide 3-kinase (PI3K)/protein kinase B (AKT)/mammalian target of rapamycin (mTOR) signaling pathway is key to physiological cellular processes that are associated with proliferation, differentiation, autophagy, apoptosis and metabolism (16,17). In addition, AMP-activated protein kinase (AMPK), a serine/threonine protein kinase, is a positive regulator of autophagy by phosphorylating ULK1 at specific sites (18). However, the detailed molecular mechanisms of various anticancer drugs involved in autophagy and apoptosis have not yet been fully investigated, and remain poorly understood.

Ginkgol C17:1, a natural monophenol refined from the Ginkgo biloba extract (EGb), is one of the most widely administered agents with spiritual, medicinal and horticultural importance worldwide (19). Studies have demonstrated that EGb has many biological benefits, such as anti-inflammatory, anti-oxidative and anticancer effects $(20,21)$. Consistent with the study by Chen et al (22), our previous study revealed that EGb could effectively inhibit cell division and induce apoptosis in cancer cell line SMMC-7721 (23). Recently, ginkgol C17:1 was demonstrated to promote cisplatin-induced apoptosis and suppress cisplatin-induced autophagy in liver cancer HepG2 cells (24). Since oral administration is the common route for chemotherapeutical agents and auxiliary chemotherapy drugs, normal cells are inevitably also exposed to chemotherapy. However, as a DNA damaging agent, cisplatin does not selectively target cancer cells, it affects normal cells as well. The cytotoxicity to normal cells may be the main cause of cisplatin-induced side effects. To date, little information exists on normal hepatocytes treated with ginkgol C17:1 monotherapy or co-treatment with cisplatin.

In the present study, hepatoma cells and normal hepatocytes were treated with ginkgol C17:1 and cisplatin in order to compare their effects on apoptosis and autophagy, and to investigate underlying molecular mechanisms or pathway networks.

\section{Materials and methods}

Reagents and antibodies. MTT, bisBenzimide H 33342 trihydrochloride (Hoechst 33342) and cisplatin were purchased from Sigma-Aldrich; Merck KGaA (Darmstadt, Germany). Penicillin and streptomycin were obtained from Harbin Pharmaceutical Group, Co., Ltd. (Harbin, China). Dulbecco's modified Eagle's medium (DMEM), RPMI-1640 medium, fetal bovine serum (FBS) and trypsin-EDTA solution were bought from Shanghai ExCell Biology, Inc. (Shanghai, China). Ginkgol C17:1 (high-performance liquid chromatography purity $>96.5 \%$ ) was obtained from the Laboratory of Food and Biological Engineering School, Jiangsu University $(23,25,26)$. Skimmed milk was purchased from Bright Dairy \& Food Co., Ltd. (Harbin, China). Adenovirus (Ad)-monomeric red fluorescent protein (mRFP)-green fluorescent protein (GFP)-light chain 3 (LC3) was purchased from Hanheng Biotechnology Co., Ltd. (Shanghai, China; https://hanhbio.biomart.cn/).

Mouse monoclonal antibody (mAb) against $\beta$-actin (cat. no. sc-47778) was obtained from Santa Cruz Biotechnology, Inc. (Dallas, TX, USA). Rabbit mAbs against Bax (cat. no. 5023), cleaved caspase-3 (cat. no. 9661), Beclin-1 (cat. no. 3495), LC3I/II (cat. no. 12741), phosphorylated (p-)mTOR ( $\operatorname{Ser}^{2448}$; cat. no. 5536), p-ULK1 (Ser ${ }^{55}$; cat. no. 5869), p-PI3K (Tyr ${ }^{458}$; cat. no. 4228) were purchased from Cell Signaling Technology, Inc. (Danvers, MA, USA). Anti-Bcl-2 (cat. no. IM001-0363) and anti-p-AKT1/2/3 (Tyr ${ }^{315 / 316 / 312}$; cat. no. IM001-0270) were purchased from Shanghai ExCell Biology, Inc. Rabbit mAb anti-SQSTM1/p62 (cat. no. ab91526) and rabbit anti-ULK1 (cat. no. ab128859) were purchased from Abcam (Cambridge, UK). Mouse anti-AMPK $\alpha 1$ (cat. no. RLM3361) and anti-p-AMPK $\alpha 1 / 2$ (Thr ${ }^{172}$; cat. no. RLM0575) were obtained from Suzhou Ruiying-Runze Trading Co., Ltd. (Suzhou, China). Horseradish peroxidase (HRP)-conjugated anti-mouse (cat. no. A0216) and anti-rabbit (cat. no. A0208) secondary antibodies were purchased from Beyotime Institute of Biotechnology (Haimen, China).

Cells and cell culture. Human hepatoma HepG2 cells and human normal L02 hepatocytes were obtained from the Institute of Cell Biology of the Chinese Academy of Sciences (Shanghai, China). HepG2 cells were cultured in DMEM and L02 cells were cultured in RPMI-1640 medium supplemented with $10 \% \mathrm{FBS}$ at $37^{\circ} \mathrm{C}$ in a humidified atmosphere containing $5 \% \mathrm{CO}_{2}$. Where indicated, cells were treated for $24 \mathrm{~h}$ with serial dilution concentrations of ginkgol C17:1 $(0,10,20,40$, 80 , or $160 \mu \mathrm{g} / \mathrm{ml})$ and/or cisplatin $(0,1,2,4,8$ or $16 \mu \mathrm{g} / \mathrm{ml})$, on the basis of previously established concentrations $(24,27)$.

MTT assay. The cells were pooled and diluted to a density of $10^{5} \mathrm{cells} / \mathrm{ml}$, and $100 \mu \mathrm{l}$ cell suspension was dispensed into each well of a 96-well plate. Following incubation for $12 \mathrm{~h}$ at $37^{\circ} \mathrm{C}$ in $5 \% \mathrm{CO}_{2}$, the cells were treated with serial dilutions of ginkgol C17:1 $(0,10,20,40,80$, or $160 \mu \mathrm{g} / \mathrm{ml})$ and/or cisplatin $(0,1,2,4,8$ or $16 \mu \mathrm{g} / \mathrm{ml})$ for $24 \mathrm{~h}$. A total of $10 \mu \mathrm{l}$ MTT $(5 \mathrm{mg} / \mathrm{ml})$ was added to each well prior to incubation for an additional $4-6 \mathrm{~h}$ at $37^{\circ} \mathrm{C}$. Subsequently, the medium was replaced with $100 \mu 1$ dimethylsulfoxide. Following thorough mixing, the absorbance was measured at an optical density of $490 \mathrm{~nm}$ using a microplate reader (Bio-Rad Laboratories, Inc., Hercules, CA, USA).

Western blotting. Protein extraction was performed according to a standard procedure outlined in previous studies $(24,27)$. 

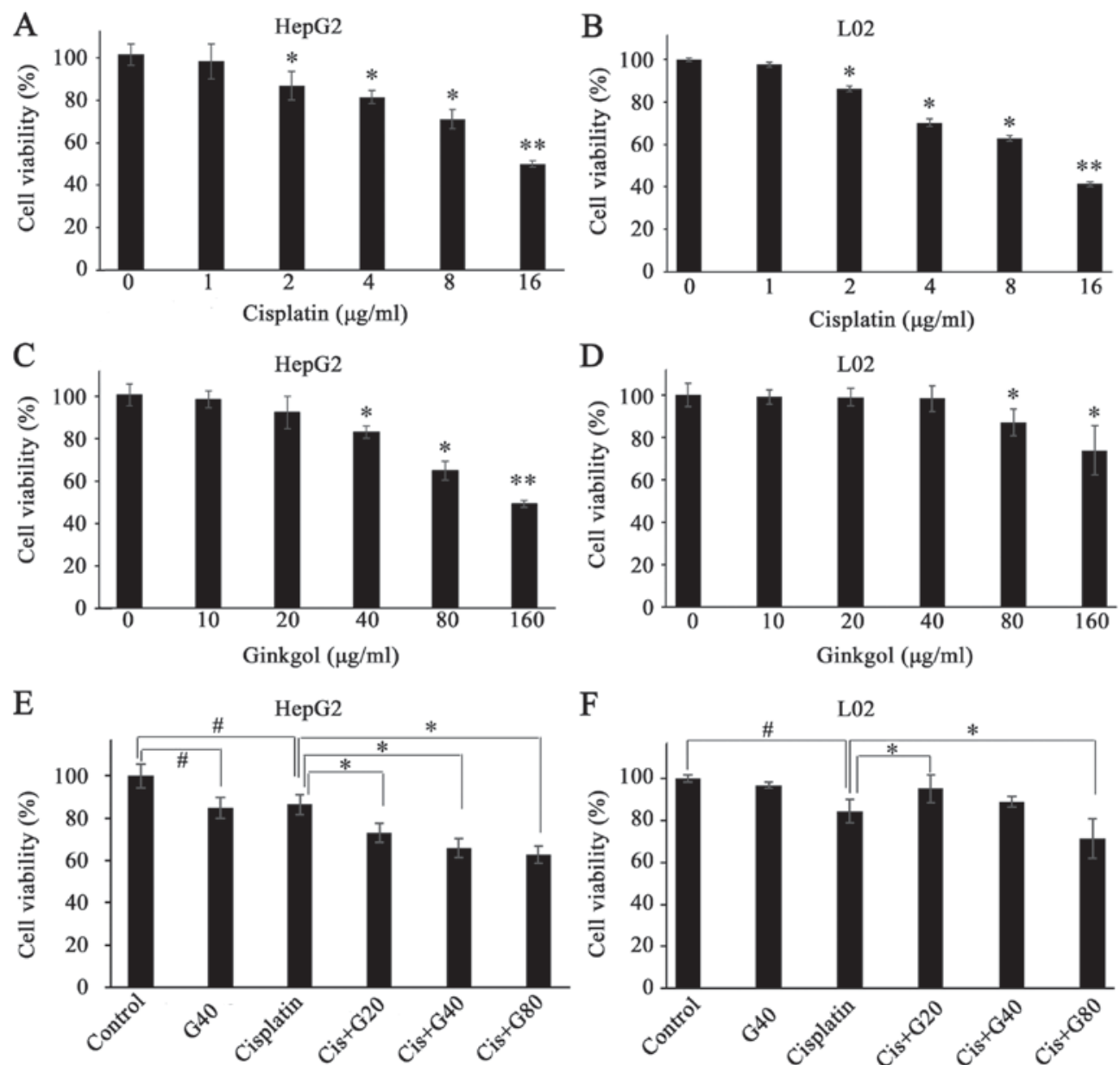

Figure 1. Effects of ginkgol C17:1 on the viability of HepG2 and L02 cells. Cell viability was determined using an MTT assay following treatment with cisplatin alone, ginkgol C17:1 or co-treatment of ginkgol C17:1 with cisplatin. (A) HepG2 cell viability following treatment with cisplatin (0, 1, 2, 4, 8 or $16 \mu \mathrm{g} / \mathrm{ml})$ for $24 \mathrm{~h}$. (B) L02 cell viability following treatment with cisplatin $(0,1,2,4,8$ or $16 \mu \mathrm{g} / \mathrm{ml})$ for $24 \mathrm{~h}$. (C) HepG2 cell viability following treatment with ginkgol C17:1 $(0,10,20,40,80$ or $160 \mu \mathrm{g} / \mathrm{ml})$ for $24 \mathrm{~h}$. (D) L02 cell viability following treatment with ginkgol C17:1 $(0,10,20,40,80 \mathrm{or} 160 \mu \mathrm{g} / \mathrm{ml})$ for $24 \mathrm{~h}$ (E) HepG2 cell viability following co-treatment with $2 \mu \mathrm{g} / \mathrm{ml}$ cisplatin and ginkgol C17:1 (20, 40 or $80 \mu \mathrm{g} / \mathrm{ml})$. (F) L02 cell viability following co-treatment with $2 \mu \mathrm{g} / \mathrm{ml}$ cisplatin and ginkgol C17:1 (20,40 or $80 \mu \mathrm{g} / \mathrm{ml})$. ${ }^{*} \mathrm{P}<0.05,{ }^{* *} \mathrm{P}<0.01 ;{ }^{*} \mathrm{P}<0.05 \mathrm{vs}$. control or as indicated. Cis, cisplatin; G20, $20 \mu \mathrm{g} / \mathrm{ml}$ ginkgol C17:1; $\mathrm{G} 40,40 \mu \mathrm{g} / \mathrm{ml}$ ginkgol C17:1; G80, $80 \mu \mathrm{g} / \mathrm{ml}$ ginkgol C17:1.

Lysis buffer ( $\mathrm{pH}$ 7.4) for protein extraction was composed of $50 \mathrm{mM}$ Tris, $150 \mathrm{mM} \mathrm{NaCl}, 1 \mathrm{mM}$ ethyl- enediaminetetraacetic acid and $1 \%$ Triton X-100. The sample proteins ( $5 \mu \mathrm{g} / \mathrm{lane}$ ) were separated on $10 \%$ SDS-PAGE (except for LC3 and cleaved caspase 3, which were separated on $8 \%$ SDS-PAGE) and transferred onto polyvinylidene difluoride (PVDF) membranes (Bio-Rad Laboratories, Inc.). The PVDF membranes were initially blocked with 5\% skimmed milk for $1 \mathrm{~h}$ at room temperature, and were then incubated with the primary antibodies AKT, p-AKT, AMPK, p-AMPK, $\beta$-actin, Bax, Bcl-2, Beclin-1, cleaved caspase-3, LC3I/II, mTOR, p-mTOR, p62, PI3K, p-PI3K, ULK1and p-ULK1 (all 1:1,000 dilution) at $4^{\circ} \mathrm{C}$ overnight. Following subsequent incubation of the membranes with HRP-conjugated secondary antibodies (1:1,000 dilution) for $1 \mathrm{~h}$ at room temperature, the western chemiluminescent HRP substrates (EMD Millipore, Billerica, MA, USA) were applied to reveal the positive bands on the membrane according to the protocol of the manufacturer. The bands were detected using MiniChemi ${ }^{\mathrm{TM}}$ miniature chemiluminescence imager (type: MiniChemi 500, software: Lan1D) (Beijing Sage Creation Science Co. Ltd, Beijing, China).
Cell autophagy flux analysis. Cells were seeded in a 24-well plate to a final density of $5 \times 10^{4}$ cells/well. Following incubation for $12 \mathrm{~h}$ at $37^{\circ} \mathrm{C}$ in $5 \% \mathrm{CO}_{2}$, the cells were infected with Ad-mRFP-GFP-LC3 for $12 \mathrm{~h}$ and treated with ginkgol $\mathrm{C} 17: 1$ or/and cisplatin for $24 \mathrm{~h}$ at $37^{\circ} \mathrm{C}$. LC3 puncta (green) in different treatment groups were observed under a fluorescence microscope (Zeiss, Oberkochen, Germany) at a magnification of x20. Calculations were performed $(28,29)$ from five different wells with same treatment using ImageJ v1.48u software (imagej.nih.gov). The results are from $\geq 3$ individual experiments.

Hoechst 33342 staining. Cells were cultured in a 24-well plate for $12 \mathrm{~h}$ at $37^{\circ} \mathrm{C}$ in $5 \% \mathrm{CO}_{2}$. Following treatment with ginkgol $\mathrm{C} 17: 1$ or/and cisplatin and incubation at $37^{\circ} \mathrm{C}$ for $24 \mathrm{~h}$, the cells were fixed with $4 \%$ paraformaldehyde for $2 \mathrm{~h}$ at room temperature. To stain the nucleus, Hoechst 33342 was added to cells for an additional $15 \mathrm{~min}$ (1:5,000 dilution). The cell nuclei in different treatment groups were visualized under a fluorescence microscope at a magnification of $\mathrm{x} 20$. The numbers of nucleus aberrations from five different wells with the same 

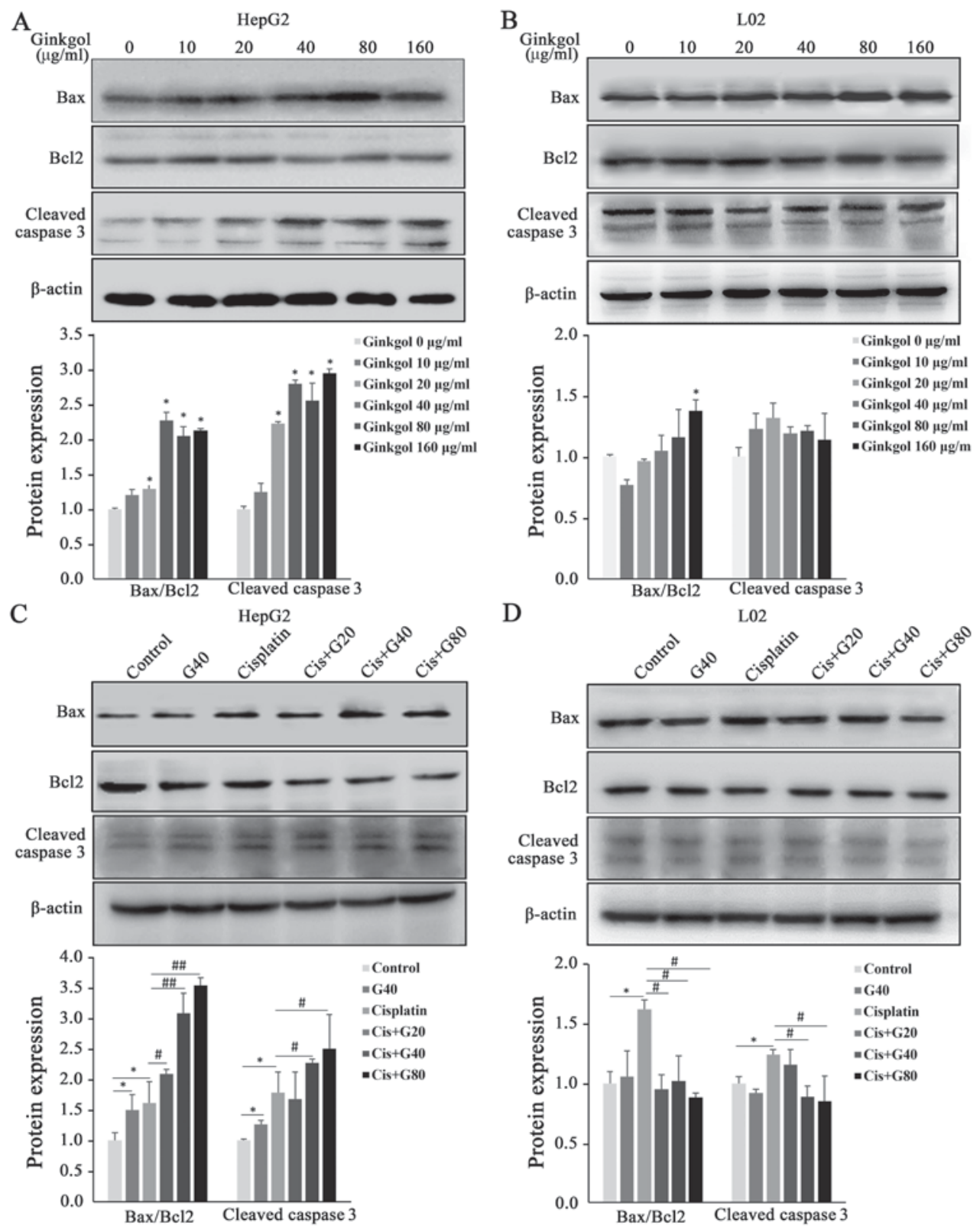

Figure 2. Expression of Bax, Bcl-2 and cleaved caspase-3 following treatment with ginkgol C17:1 and/or cisplatin in HepG2 and L02 cells. Protein expression of Bax, Bcl-2 and cleaved caspase-3 were analyzed by western blotting. (A) HepG2 cells treated with ginkgol C17:1 (0, 10, 20, 40, $80 \mathrm{or} 160 \mu \mathrm{g} / \mathrm{ml})$ for $24 \mathrm{~h}$ (B) L02 cells treated with ginkgol C17:1 (0, 10,20,40,80 or $160 \mu \mathrm{g} / \mathrm{ml})$ for $24 \mathrm{~h}$. (C) HepG2 cells co-treated with $2 \mu \mathrm{g} / \mathrm{ml}$ cisplatin and ginkgol C17:1 (20, 40 or $80 \mu \mathrm{g} / \mathrm{ml}$ ) for $24 \mathrm{~h}$. (D) L02 cells co-treated with $2 \mu \mathrm{g} / \mathrm{ml}$ cisplatin and ginkgol C17:1 (20,40 or $80 \mu \mathrm{g} / \mathrm{ml})$ for $24 \mathrm{~h}$. Results are presented as the mean \pm standard deviation for five independent experiments. " $\mathrm{P}<0.05$ vs. control; " $\mathrm{P}<0.05$ and ${ }^{\# \# /} \mathrm{P}<0.01$ vs. cisplatin alone. Bcl-2, B-cell lymphoma 2; Bax, Bcl-2-associated $\mathrm{X}$ protein. Cis, cisplatin; G20, $20 \mu \mathrm{g} / \mathrm{ml}$ ginkgol C17:1; G40, $40 \mu \mathrm{g} / \mathrm{ml}$ ginkgol C17:1; G80, $80 \mu \mathrm{g} / \mathrm{ml}$ ginkgol C17:1.

treatment were determined (24) using Image J. The results are from $\geq 3$ individual experiments.

Statistical analysis. All data are presented as the mean \pm standard deviation. One-way analysis of variance was used to analyze differences between experimental groups using SPSS version 16.0 software (SPSS, Inc., Chicago, IL, USA). Dunnett of multiple comparisons was used as post hoc test. $\mathrm{P}<0.05$ was considered to indicate a statistically significant difference.

\section{Results}

Effects of ginkgol C17:1 combined with cisplatin on cell viability in hepatoma HepG2 and normal LO2 hepatocytes. Cell viability was determined using the MTT assay following $24 \mathrm{~h}$ of incubation with ginkgol C17:1 alone, cisplatin alone or ginkgol C17:1 with cisplatin (co-treatment). As the most commonly administered chemotherapy drug, cisplatin $(2-16 \mu \mathrm{g} / \mathrm{ml})$ decreased the viability of hepatoma HepG2 cells (Fig. 1A) and that of normal hepatocytes (Fig. 1B), in a concentration-dependent manner. Whereas ginkgol C17:1 significantly decreased the viability of HepG2 cells at concentrations of 40,80 and $160 \mu \mathrm{g} / \mathrm{ml}$ (Fig. 1C), this effect was only observed in L02 cells treated with 80 and $160 \mu \mathrm{g} / \mathrm{ml}$ ginkgol C17:1 (Fig. 1D). The results of the co-treatment of cisplatin $(2 \mu \mathrm{g} / \mathrm{ml})$ with ginkgol C17:1 $(20,40$ and $80 \mu \mathrm{g} / \mathrm{ml})$ indicated that ginkgol C17:1 significantly enhanced the cisplatin-induced inhibition of HepG2 cell viability (Fig. 1E). However, in normal L02 hepatocytes, 


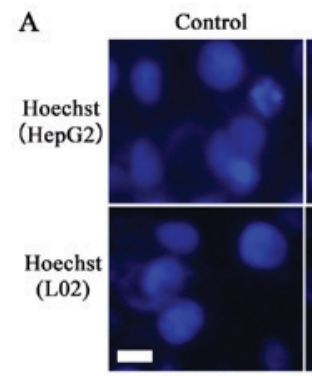

B

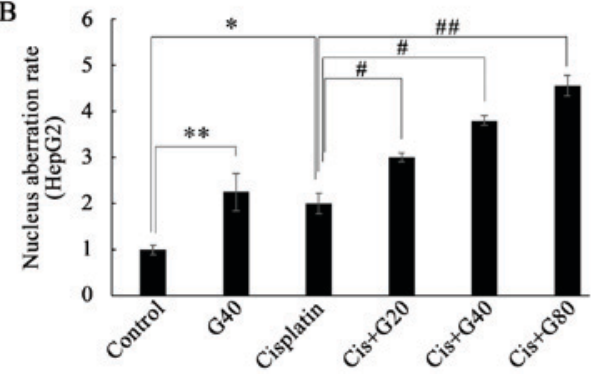

Cisplatin

G40
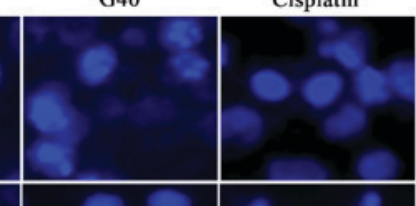

$\mathrm{Cis}+\mathrm{G} 20$ Cis $+\mathrm{G} 20$
Cis $+\mathrm{G} 40$

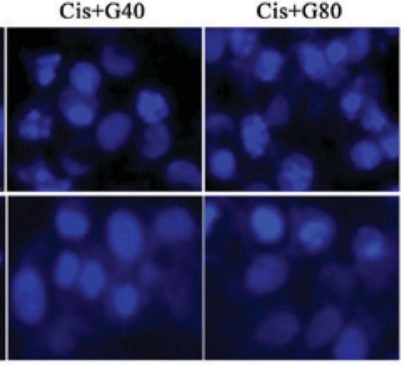

C

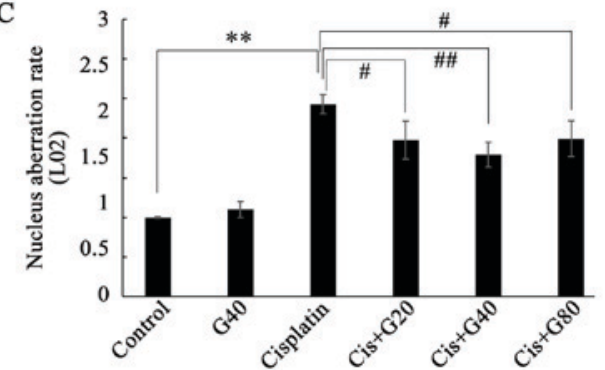

Figure 3. Morphological changes of cell nuclei following treatment with ginkgol C17:1 and/or cisplatin in HepG2 and L02 cells. Nuclear aberrations were revealed by immunofluorescence microscopy (magnification, x200) following staining with Hoechst 33342. (A) Nuclear aberrations visualized in HepG2 cells (upper panels) and in L02 cells (lower panels). Scale bar, $10 \mu \mathrm{m}$. Corresponding nuclear aberration rates (relative to control group) were determined for (B) HepG2 cells and (C) L02 cells. Results are the mean \pm standard deviation for five independent experiments. ${ }^{*} \mathrm{P}<0.05$ and ${ }^{* *} \mathrm{P}<0.01$ vs. control); ${ }^{\#} \mathrm{P}<0.05$ and ${ }^{\# \#} \mathrm{P}<0.01$ vs. cisplatin alone. Cis, cisplatin; G20, $20 \mu \mathrm{g} / \mathrm{ml}$ ginkgol C17:1; G40, $40 \mu \mathrm{g} / \mathrm{ml}$ ginkgol C17:1; G80, 80 $\mu \mathrm{g} / \mathrm{ml}$ ginkgol C17:1.

enhanced inhibition of cell viability was observed only for the co-treatment with $80 \mu \mathrm{g} / \mathrm{ml}$ ginkgol C17:1. Notably, ginkgol $\mathrm{C} 17: 1$ at the lower concentration of $20 \mu \mathrm{g} / \mathrm{ml}$ reversed the inhibitory effect of cisplatin in L02 cells (Fig. 1F).

Effects of ginkgol C17:1 with cisplatin on apoptosis in HepG2 and LO2 cells. Apoptosis is the primary response of cells to chemotherapeutic agents, including cisplatin, an effective anticancer drug with a major clinical effect (6). To determine the occurrence of apoptosis induced by ginkgol C17:1 alone or by co-treatment with cisplatin, key proteins involved in apoptosis were analyzed using western blotting. In hepatoma HepG2 cells, ginkgol C17:1 alone significantly increased protein levels of pro-apoptotic Bax and cleaved caspase-3, but decreased the level of the anti-apoptotic Bcl-2 (Fig. 2A). Along with the trend of increase, Bax/Bcl 2 and cleaved caspase-3 increased significantly at the doses higher than $20 \mu \mathrm{g} / \mathrm{ml}$ ginkgol C17:1. As demonstrated in Fig. 2B, no significant effects on the proteins were observed in normal L02 hepatocytes treated with ginkgol $\mathrm{C} 17: 1$, except a significant increase of $\mathrm{Bax} / \mathrm{Bcl} 2$ at the higher dose $160 \mu \mathrm{g} / \mathrm{ml}$ (Fig. 2B). While cisplatin alone induced significant increases of Bax and cleaved caspase-3, and a decrease in Bcl-2 in the HepG2 and L02 cells, the co-treatment exhibited distinct effects on the two cell types. In the HepG2 cells, the co-treatment promoted the increased expression of Bax and cleaved caspase- 3 and further decreased the levels of $\mathrm{Bcl}-2$, showing the significant increases in both $\mathrm{Bax} / \mathrm{Bcl} 2$ and cleaved caspase-3 except for cleaved caspase- 3 at co-treatment of $20 \mu \mathrm{g} / \mathrm{ml}$ ginkgol C17:1 having no change (Fig. 2C). In the L02 cells, however, the co-treatment significantly reversed the cisplatin-induced increase in Bax, and the protein levels of cleaved caspase- 3 and Bcl-2 were comparable with those in the untreated cells except that caspase- 3 at co-treatment of $20 \mu \mathrm{g} / \mathrm{ml}$ ginkgol C17:1 was similar to that in the group of cisplatin alone (Fig. 2D).
Hoechst 33342 dye was used for visualization of the apoptotic aberrations in the cell nuclei following various treatments. As presented in Fig. 3, cisplatin alone significantly induced nuclear aberrations in HepG2 and L02 cells, whereas ginkgol C17:1 alone caused nuclear aberrations in HepG2 cells, but did not alter the morphology of nuclei in L02 cells. Under the co-treatment conditions, ginkgol C17:1 significantly enhanced the nuclear aberration caused by cisplatin in the HepG2 cells, in a concentration-dependent manner (Fig. 3B). In contrast, in L02 cells, ginkgol C17:1 significantly decreased the effect of cisplatin on the apoptotic nuclear aberration rate (Fig. 3C).

Effects of ginkgol C17:1 with cisplatin on autophagy in HepG2 and LO2 cells. By detecting the expression of key proteins involved in the process of autophagy, ginkgol C17:1 alone was revealed to significantly increase the protein levels of Beclin-1 and LC3I/II, and decrease p62 levels in hepatoma HepG2 cells (Fig. 4A) and normal L02 hepatocytes (Fig. 4B). As presented in Fig. 4C, cisplatin alone also enhanced autography in HepG2 cells, indicated by increased protein levels of Beclin-1 and LC3I/II and decreased levels of p62. However, the cisplatin-induced autography was significantly attenuated in the co-treatment (Fig. 4C). In L02 cells, in comparison with the lack of effect on the Beclin-1, LC3I/II and p62 protein levels by cisplatin alone, ginkgol C17:1 alone and the co-treatment induced an increase in Beclin-1 and LC3I/II, and a decrease in p62 (Fig. 4D).

In agreement with the results of the western blotting, the LC3 punctum assay (Fig. 5) revealed that ginkgol C17:1 or cisplatin alone enhanced autophagy in HepG2 cells, with the increase in LC3 puncta indicated by the fluorescence intensity of LC3 scattered throughout the cytoplasm. However, in the co-treatment, ginkgol C17:1 significantly inhibited cisplatin-induced autophagy (Fig. 5B). The LC3 punctum assay also confirmed the results of the western blotting in the L02 cells, revealing that ginkgol C17:1 induced autophagy not 
A

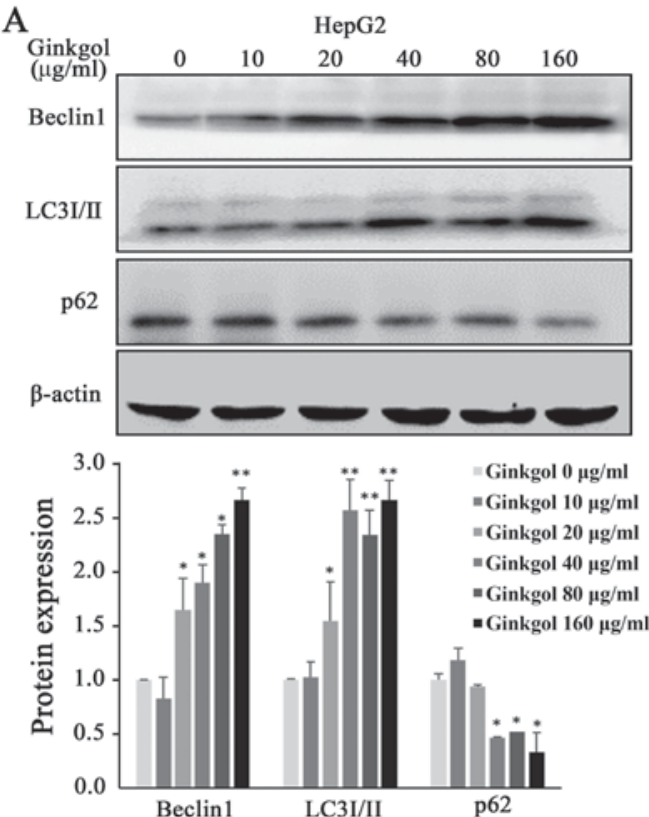

$\mathrm{C}$

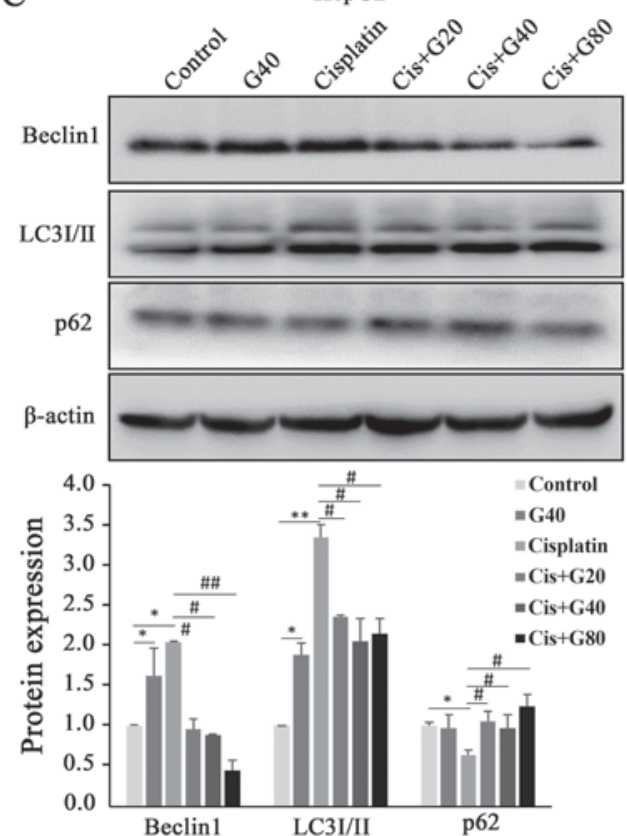

B
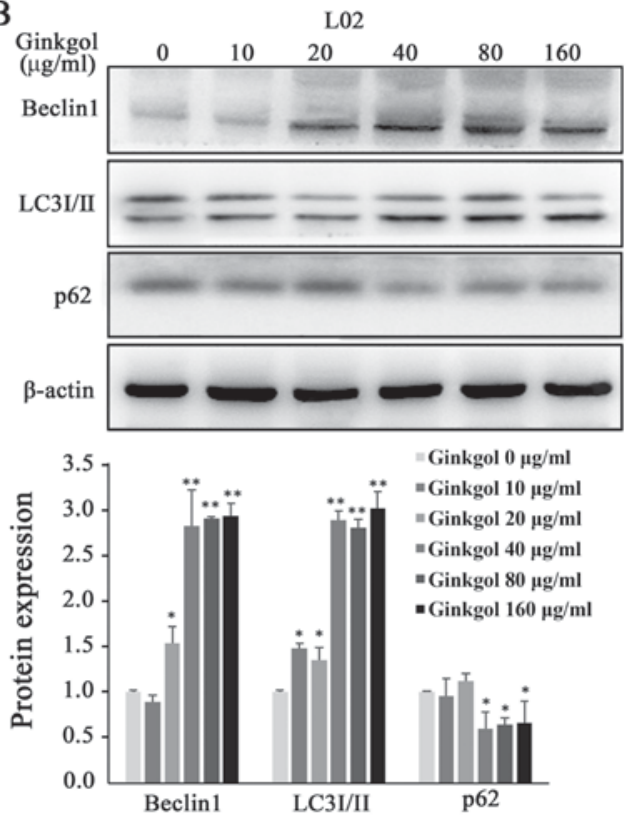

D L02

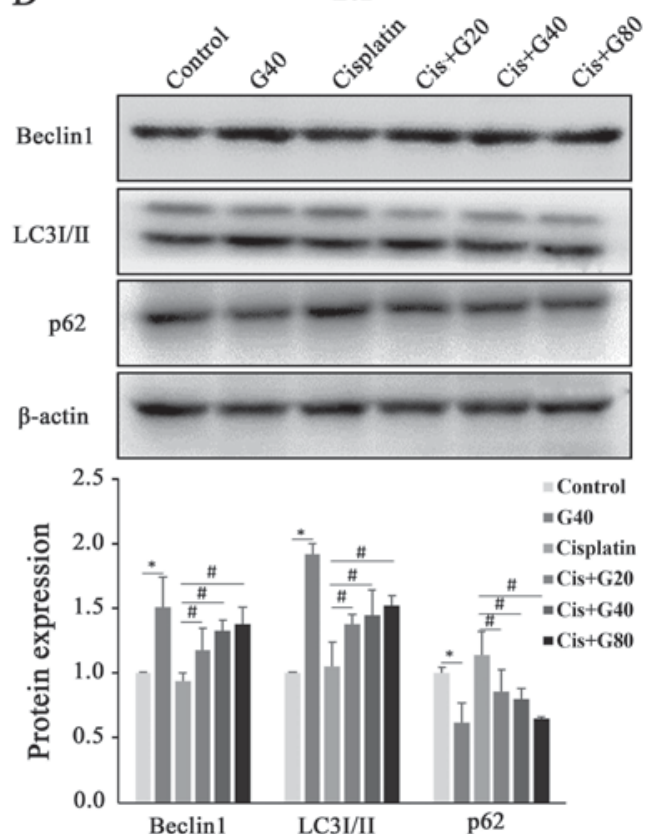

Figure 4. Expression of Beclin1, LC3I/II and p62 following treatment with ginkgol C17:1 and/or cisplatin in HepG2 and L02 cells. The expression of Beclin1, LC3I/II and p62 was analyzed by western blotting. (A) HepG2 cells treated with ginkgol C17:1 (0, 10, 20, 40, 80 or 160 $\mu \mathrm{g} / \mathrm{ml})$ for 24 h. (B) L02 cells treated with ginkgol C17:1 $(0,10,20,40,80$ or $160 \mu \mathrm{g} / \mathrm{ml})$ for $24 \mathrm{~h}$. (C) HepG2 cells co-treated with $2 \mu \mathrm{g} / \mathrm{ml}$ cisplatin and ginkgol C17:1 (20, 40 or $80 \mu \mathrm{g} / \mathrm{ml})$ for $24 \mathrm{~h}$. (D) L02 cells treated with $2 \mu \mathrm{g} / \mathrm{ml}$ cisplatin and ginkgol C17:1 (20, $40 \mathrm{or} 80 \mu \mathrm{g} / \mathrm{ml})$ for $24 \mathrm{~h}$. Results are the mean \pm standard deviation for five independent experiments. ${ }^{*} \mathrm{P}<0.05$ and ${ }^{* *} \mathrm{P}<0.01$ vs. control; ${ }^{*} \mathrm{P}<0.05$ and ${ }^{\# \#} \mathrm{P}<0.01$ vs. cisplatin alone. LC3, light chain 3; Cis, cisplatin; G20, 20 $\mu$ g/ml ginkgol C17:1; G40, $40 \mu \mathrm{g} / \mathrm{ml}$ ginkgol C17:1; G80, $80 \mu \mathrm{g} / \mathrm{ml}$ ginkgol C17:1.

only when administered alone, but also in the co-treatment with cisplatin (Fig. 5C). Although the difference between co-treatment with $20 \mu \mathrm{g} / \mathrm{ml}$ ginkgol C17:1 and cisplatin alone was statistically insignificant, LC3 puncta rate did exhibit a trend of increase in autophagy.

Ginkgol C17:1 affects the AMPK/ULK1 and PI3K/AKT/mTOR signaling pathways in HepG2 and LO2 cells. To investigate potential underlying molecular mechanisms, western blotting was used to determine the levels of proteins involved in the AMPK/ULK1 and PI3K/AKT/mTOR signaling pathways, which are associated with autophagy or apoptosis. As presented in Fig. 6A, increased amounts of AMPK and ULK1, particularly their phosphorylated forms, indicating the activation of the AMPK/ULK1 signaling pathway, were observed following the treatment of HepG2 cells with ginkgol $\mathrm{C} 17: 1$ or cisplatin alone. However, in comparison with cisplatin alone, co-treatment with ginkgol C17:1 reversed this activation in hepatoma HepG 2 cells. In normal L02 hepatocytes, ginkgol C17:1 alone activated the AMPK/ULK1 pathway, whereas cisplatin alone did not significantly alter the protein expression of AMPK and ULK1, or that of their phosphorylated forms 

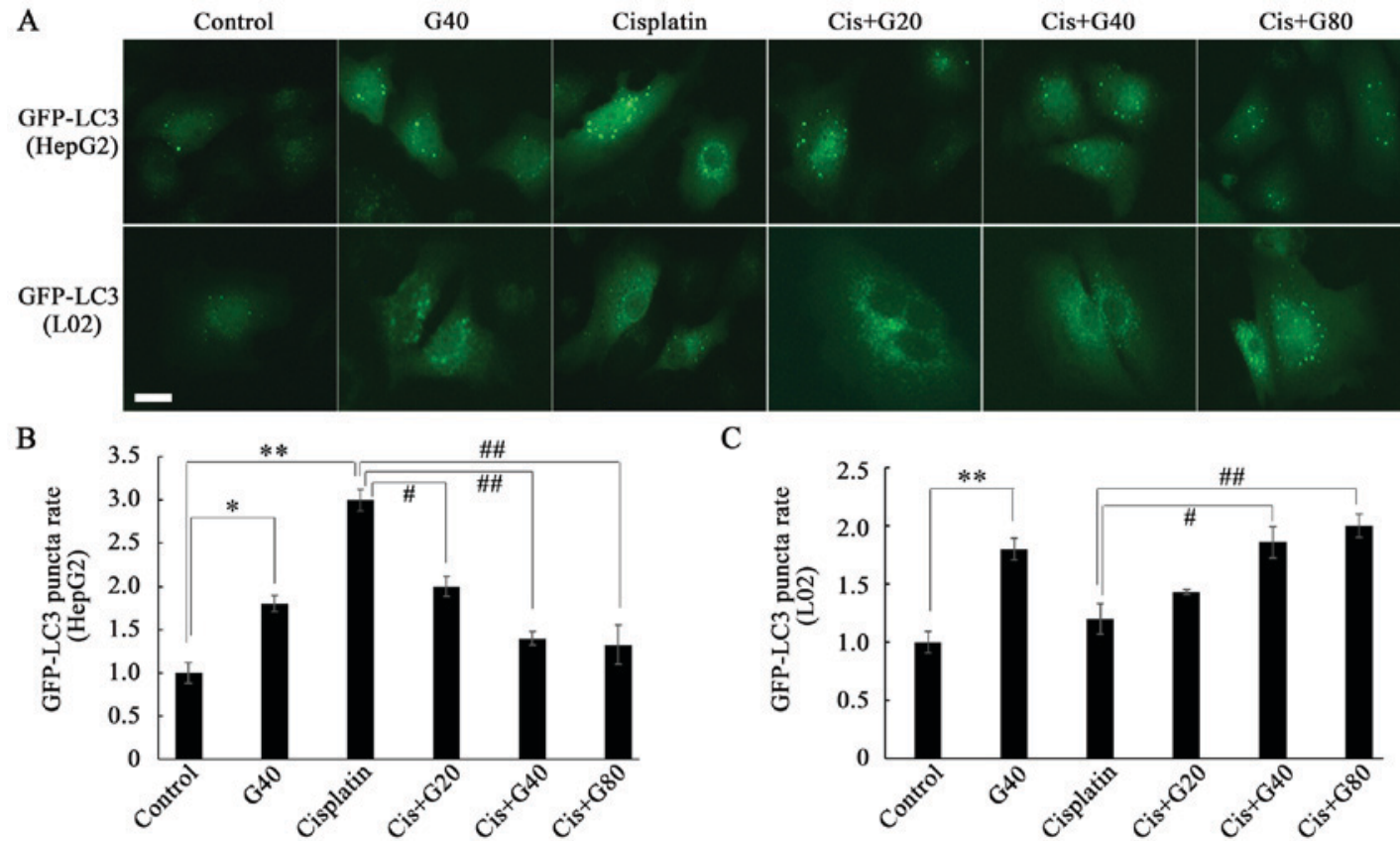

Figure 5. Formation of GFP-LC3 puncta following treatment with ginkgol C17:1 and/or cisplatin in HepG2 and L02 cells. Autophagy protein LC3 was determined by immunofluorescence assay (magnification, x200) following infection with GFP-LC3 adenovirus and treatment with $2 \mu \mathrm{g} / \mathrm{ml}$ cisplatin and/or ginkgol C17:1 $(20,40$, or $80 \mu \mathrm{g} / \mathrm{ml})$ for $24 \mathrm{~h}$. (A) GFP-LC3 puncta in HepG2 cells (upper panel) and L02 cells (lower panel). Scale bar, $20 \mu \mathrm{m}$. The relative rates of GFP-LC3 puncta to control group were determined for (B) HepG2 cells and (C) L02 cells. Results are the mean \pm SD for five independent experiments. ${ }^{*} \mathrm{P}<0.05,{ }^{* *} \mathrm{P}<0.01 ;{ }^{\#} \mathrm{P}<0.05,{ }^{\# \#} \mathrm{P}<0.01$. GFP, green fluorescent protein; LC3, light chain 3; Cis, cisplatin; G20, $20 \mu \mathrm{g} / \mathrm{ml}$ ginkgol C17:1; G40, $40 \mu$ g/ml ginkgol $\mathrm{C} 17: 1 ; \mathrm{G} 80,80 \mu \mathrm{g} / \mathrm{ml}$ ginkgol C17:1.

(Fig. 6B). Compared with cisplatin alone, the co-treatment led to an increase in the levels of AMPK and ULK1, and their phosphorylation (Fig. 6B).

In HepG2 cells (Fig. 6C), ginkgol C17:1 or cisplatin alone inhibited the phosphorylation of PI3K, AKT and mTOR. Under the conditions of co-treatment, ginkgol C17:1 further decreased the levels of p-PI3K and p-mTOR in a concentration-dependent manner, whereas with the trend of further decline, the levels of p-AKT decreased significantly at the co-treatment with higher doses than $20 \mu \mathrm{g} / \mathrm{ml}$. In L02 cells, however (Fig. 6D), cisplatin alone inhibited the protein expression of p-PI3K, p-AKT and p-mTOR, but ginkgol C17:1 did not significantly alter the protein amounts of $\mathrm{p}-\mathrm{PI} 3 \mathrm{~K}, \mathrm{p}-\mathrm{AKT}$ and p-mTOR. Co-treatment reversed the inhibitory effects of cisplatin on PI3K/AKT/mTOR. Co-treatment doses higher than $20 \mu \mathrm{g} / \mathrm{ml}$ led to further increased amounts of $\mathrm{p}-\mathrm{PI} 3 \mathrm{~K}$, p-AKT and p-mTOR compared to untreated cells.

\section{Discussion}

Chemotherapy continues to be a common method in the treatment of cancer. Cisplatin, a metal-based compound which was identified half a century ago, remains the mainstay of the most widely used chemotherapeutics for treating cancer (30). However, owing to drug resistance and multiple side effects of cisplatin, it is imperative for physicians to identify a novel approach to improve its anticancer effect, ideally aiming to kill only cancer cells while leaving normal cells unharmed (31). According to this concept, auxiliary chemotherapy drugs synergizing the cytotoxicity at relatively low dose of chemotherapeutical agents would be beneficial to kill cancer cells with minor side effects on normal cells.
The cell viability results of the present study confirmed the comparable cytotoxicity in cancer and normal hepatocytes. Whereas ginkgol C17:1 induced a cytotoxic effect in hepatoma cells, it inhibited the viability of normal hepatocytes only at higher doses $(\geq 80 \mu \mathrm{g} / \mathrm{ml})$. Importantly, the combination of ginkgol C17:1 with a low dose of cisplatin $(2 \mu \mathrm{g} / \mathrm{ml})$ exhibited prominent cytotoxicity in hepatoma cells, but with less (or no) toxicity in normal hepatocytes.

Previous studies indicated that cisplatin is able to induce autophagy and apoptosis in cancer cells of different origins $(24,32,33)$. Consistently exhibiting the same cisplatin cytotoxicity in liver cancer HepG2 cells, the results of the present study also confirmed cisplatin-induced apoptosis in normal hepatocyte L02 cells. Unlike in HepG2 cells, cisplatin did not cause any significant alteration in the autophagic activity of L02 cells. These results indicated that apoptosis may be the primary cytotoxic response to cisplatin in normal hepatocytes.

Previous studies suggested that ginkgols can inhibit hepatoma cell viability, migration and invasion, even ultimately leading to apoptosis by inducing the expression of caspases $(21,34)$. In the present study, ginkgol C17:1 was identified to lead to an increase in apoptosis, characterized by cell shrinkage, nucleus condensation and the increased expression of apoptotic proteins Bax and cleaved caspase 3 compared with a decreased expression of Bcl-2 in human liver cancer HepG2 cells. In the co-treatment, ginkgol C17:1 promoted the cisplatin-induced apoptosis in HepG 2 cells. In contrast, no apoptosis was induced by ginkgol C17:1 alone in normal hepatocyte $\mathrm{L} 02$ cells. When co-treated with cisplatin, ginkgol C17:1 even inhibited cisplatin-induced apoptosis in normal hepatocyte L02 cells. These results indicated the anticancer effect 
A

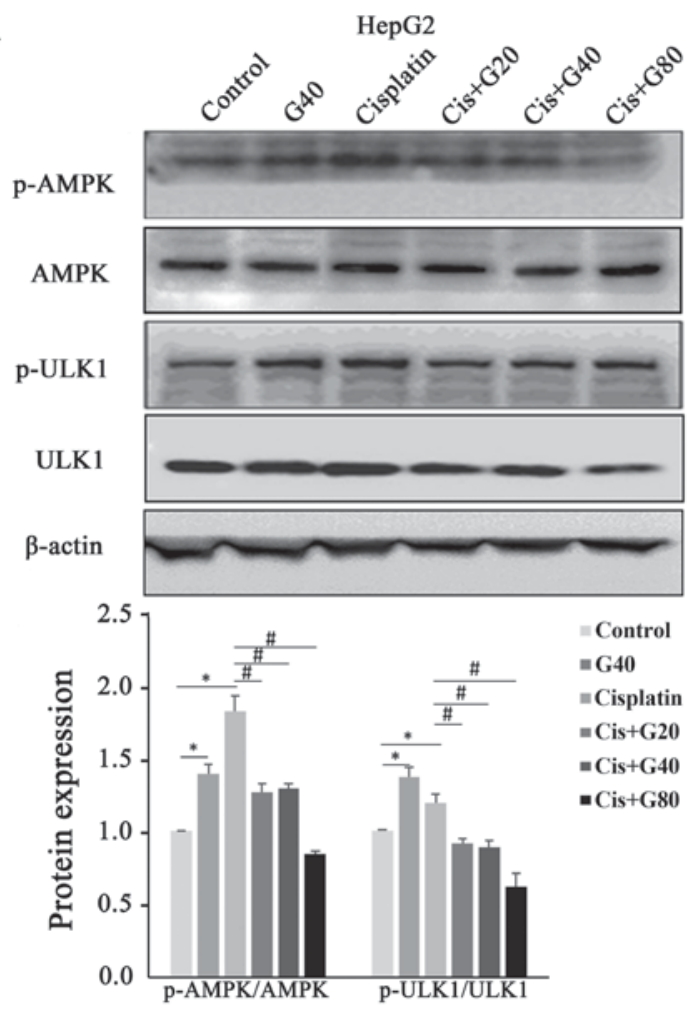

$\mathrm{C}$
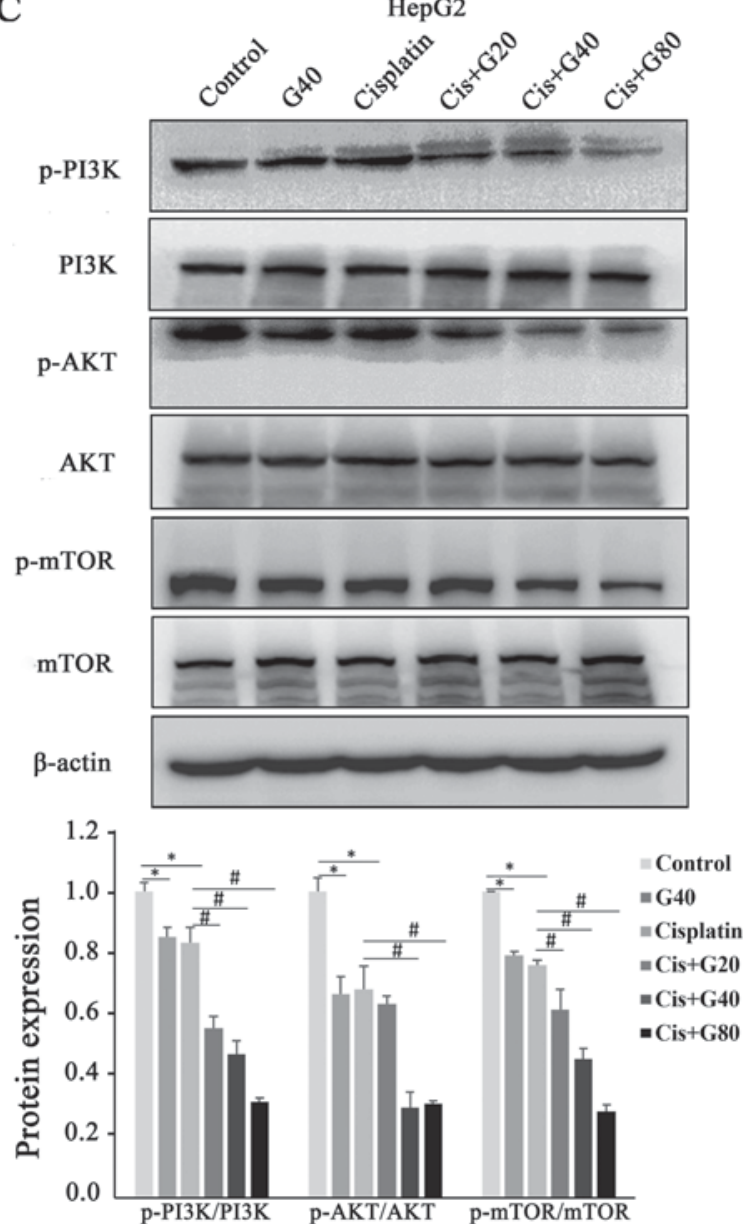

B

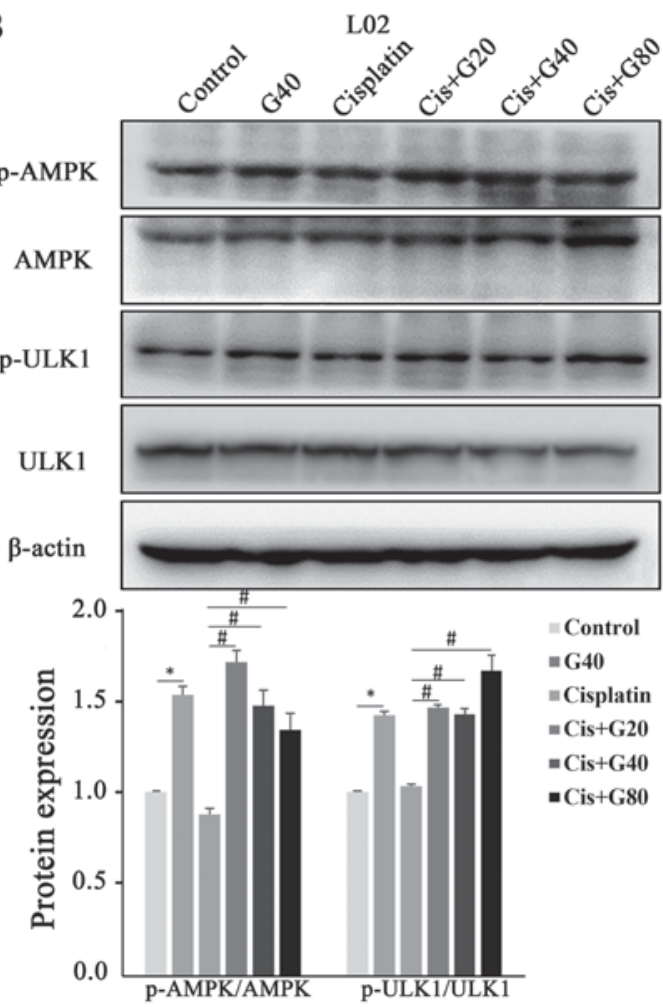

$\mathrm{D}$

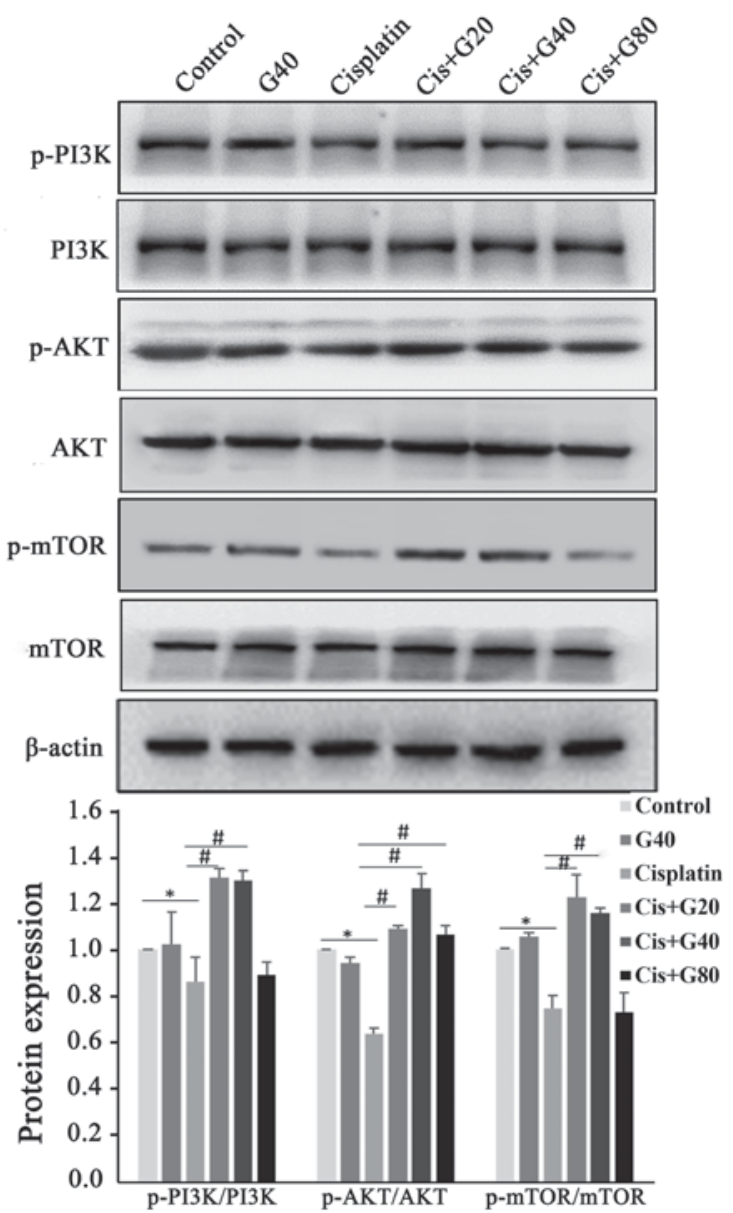

Figure 6. Effect of ginkgol C17:1 and/or cisplatin on AMPK/ULK1 and PI3K/AKT/mTOR signaling pathways. Following treatment with $2 \mu \mathrm{g} / \mathrm{ml}$ cisplatin and/or ginkgol C17:1 $(0,20,40$ or $80 \mu \mathrm{g} / \mathrm{ml})$ for $24 \mathrm{~h}$, western blotting was performed to determine the expression of phosphorylated AMPK (Thr $\left.{ }^{172}\right)$, phosphorylated ULK1 (Ser ${ }^{55}$ ) in (A) HepG2 cells and (B) L02 cells. The expression of upstream pathway phosphorylated PI3K (Tyr ${ }^{458}$ ), phosphorylated AKT $\left(\mathrm{Th}^{308}\right.$ ), phosphorylated mTOR ( $\mathrm{Se}^{2448}$ ) in (C) HepG2 cells and (D) L02 cells. Results are the mean \pm standard deviation for five independent experiments. ${ }^{\text {"P }}<0.05$ vs. control; " $\mathrm{P}<0.05$ vs. cisplatin alone. AMPK, AMP-activated protein kinase; PI3K, phosphoinositide 3-kinase; AKT, protein kinase B; mTOR, mammalian target of rapamycin; Cis, cisplatin; G20, $20 \mu \mathrm{g} / \mathrm{ml}$ ginkgol C17:1; G40, $40 \mu \mathrm{g} / \mathrm{ml}$ ginkgol C17:1; G80, $80 \mu \mathrm{g} / \mathrm{ml}$ ginkgol C17:1; p-, phosphor. 
of ginkgol C17:1 in liver cancer cells without killing normal hepatocytes. More importantly, while protecting normal cells from cisplatin-induced apoptosis, ginkgol C17:1 improves the chemotherapeutic effect of cisplatin via enhancing cisplatin-induced apoptosis in cancer cells.

Autophagy is normally known as a survival mechanism to clean up the damage signals to protect cells from injury. In cancer cells, however, induction of autophagy has been implicated in the resistance to multiple standard chemotherapeutic agents such as cisplatin $(13,35,36)$. A number of studies have identified that inhibition of autophagy may enhance chemosensitization in human cancer cells (37-39). In the present study, although ginkgol C17:1 alone induced autophagy in hepatoma HepG2 cells, in conjunction with cisplatin, however, ginkgol C17:1 inconceivably inhibited the cisplatin-induced autophagy to a marked extent. The inhibition of cisplatin-induced autophagy together with the enhancement of cisplatin-induced apoptosis suggested a promising combination of ginkgol C17:1 with cisplatin for chemosensitization of cancer cells in cisplatin chemotherapy. Furthermore, autophagy was increased in L02 cells by ginkgol C17:1 monotherapy and particularly upon co-treatment with cisplatin. The induction of autophagy and the inhibition of cisplatin-induced apoptosis indicated a protective effect of ginkgol C17:1 in normal hepatocytes, when co-exposed to cisplatin during chemotherapy. This protective role of ginkgol C17:1 on cisplatin-induced cytotoxicity in L02 cells further supported the potential of co-treatment of ginkgol C17:1 with cisplatin with minor side effects on normal cells in cisplatin chemotherapy.

Previous studies have identified that autophagy provides a survival advantage against cancer therapies by inducing AMPK and suppressing apoptosis $(40,41)$. In liver hepatoma HepG2 cells, although ginkgol C17:1 alone induced autophagy by activating AMPK signaling pathway, it did inhibit cisplatin-induced autophagy by decreasing the activity of the AMPK signaling pathway and enhancing the cisplatin-induced apoptosis. Suppression of autophagy increased HepG2 cell death through inhibition of AMPK upon co-treatment of ginkgol C17:1 with cisplatin. In normal hepatocyte L02 cells, although cisplatin did not significantly affect the AMPK/ULK1 signaling pathway, ginkgol C17:1 activated the AMPK/ULK1 signaling pathway to induce autophagy that can restore the damage caused by cisplatin. Inhibition of the PI3K/AKT/mTOR signaling pathway is considered to inhibit cell proliferation and autophagy, thus contributing to anticancer mechanisms $(42,43)$. In the present study, treatment with ginkgol C17:1 or cisplatin alone inhibited the PI3K/AKT/mTOR signaling pathway in liver cancer HepG2 cells and a more marked inhibition was observed upon co-treatment. In normal hepatocytes, ginkgol C17:1 alone did not cause a significant change in this signaling pathway, but it decreased the inhibition caused by cisplatin. These changes in the PI3K/AKT/mTOR signaling pathway were consistent with the results of apoptosis and autophagy, indicating the involvement of the PI3K/AKT/mTOR signaling pathway in altering apoptosis or autophagy by ginkgol C17:1 or cisplatin. We hypothesize that ginkgol C17:1 sensitizes liver cancer HepG2 cells to cisplatin chemotherapy via synergistic inhibition of the PI3K/AKT/mTOR signaling pathway, whereas repairing the PI3K/AKT/mTOR signaling pathway may contribute to the mechanism of ginkgol C17:1 in protecting normal hepatocyte
L02 cells against cisplatin-induced cytotoxicity. However, the exact molecular mechanisms such as which upstream targets are involved require further clarification.

In conclusion, to the best of our knowledge, the results of the present study provided the first evidence that, ginkgol C17:1 can protect normal hepatocytes against cisplatin-caused cytotoxicity while potentiating the anticancer effect of cisplatin chemotherapy. The differential effects upon co-treatment of ginkgol C17:1 with cisplatin in hepatoma and normal hepatocytes suggest that ginkgol C17:1 may be a promising candidate for auxiliary chemotherapy, meeting the modern concept of developing therapeutics that would selectively target cancer cells and leave healthy cells unharmed or less harmed. Further investigations such as in vivo studies on animal models are currently underway.

\section{Acknowledgements}

Not applicable.

\section{Funding}

This work was supported by the National Natural Science Foundation of China (grant no. 81372404) and the College Students' Scientific Research Project of Jiangsu University (grant nos. 16A511 and 16A513).

\section{Availability of data and materials}

All data generated or analyzed during this study are included in this published article.

\section{Authors' contributions}

YL designed the study, measured the signaling pathways and participated in manuscript preparation. XZ performed experiments concerning apoptosis and autophagy. XY and JL isolated ginkgol C17:1, participated in data analysis and prepared the figures, LL performed experiments on immunofluorescence. WM performed the MTT assay and statistical analysis. MC analyzed data and was a major contributor in writing the manuscript. All authors read and approved the final manuscript.

\section{Ethics approval and consent to participate}

Not applicable.

\section{Patient consent for publication}

Not applicable.

\section{Competing interests}

The authors declare that they have no competing interests.

\section{References}

1. Pascual S, Herrera I and Irurzun J: New advances in hepatocellular carcinoma. World J Hepatol 8: 421-438, 2016.

2. Marquardt JU, Andersen JB and Thorgeirsson SS: Functional and genetic deconstruction of the cellular origin in liver cancer. Nat Rev Cancer 15: 653-667, 2015. 
3. Sun BS, Dong QZ, Ye QH, Sun HJ, Jia HL, Zhu XQ, Liu DY, Chen J, Xue Q, Zhou HJ, et al: Lentiviral-mediated miRNA against osteopontin suppresses tumor growth and metastasis of human hepatocellular carcinoma. Hepatology 48: 1834-1842, 2008.

4. Yang Y, Lu Y, Wang C, Bai W, Qu J, Chen Y, Chang X, An L, Zhou L, Zeng Z, et al: Cryotherapy is associated with improved clinical outcomes of Sorafenib therapy for advanced hepatocellular carcinoma. Cell Biochem Biophys 63: 159-169, 2012.

5. Boulikas T and Vougiouka M: Cisplatin and platinum drugs at the molecular level (Review). Oncol Rep 10: 1663-1682, 2003.

6. Kelland L: The resurgence of platinum-based cancer chemotherapy. Nat Rev Cancer 7: 573-584, 2007.

7. Markman M: Toxicities of the platinum antineoplastic agents. Expert Opin Drug Saf 2: 597-607, 2003.

8. Hu XC, Zhang J, Xu BH, Cai L, Ragaz J, Wang ZH, Wang BY, Teng YE, Tong ZS, Pan YY, et al: Cisplatin plus gemcitabine versus paclitaxel plus gemcitabine as first-line therapy for metastatic triple-negative breast cancer (CBCSG006): A randomised, open-label, multicentre, phase 3 trial. Lancet Oncol 16: 436-446, 2015.

9. Mizushima N and Komatsu M: Autophagy: Renovation of cells and tissues. Cell 147: 728-741, 2011.

10. Lu SZ and Harrison-Findik DD: Autophagy and cancer. World J Biol Chem 4: 64-70, 2013.

11. White E: The role for autophagy in cancer. J Clin Invest 125 : 42-46, 2015.

12. Amaravadi R, Kimmelman AC and White E: Recent insights into the function of autophagy in cancer. Genes Dev 30: 1913-1930, 2016.

13. Chen J, Wang Q, Yin FQ, Zhang W, Yan LH and L Li: MTRR silencing inhibits growth and cisplatin resistance of ovarian carcinoma via inducing apoptosis and reducing autophagy. Am J Transl Res 7: 1510-1527, 2015.

14. Nikoletopoulou V, Markaki M, Palikaras K and Tavernarakis N: Crosstalk between apoptosis, necrosis and autophagy. Biochim Biophys Acta 1833: 3448-3359, 2013.

15. Li F, Zeng J, Gao Y, Guan Z, Ma Z, Shi Q, Du C, Jia J, Xu S, Wang X, et al: G9a inhibition induces autophagic cell death via AMPK/mTOR pathway in bladder transitional cell carcinoma. PLoS One 10: e0138390, 2015.

16. Vanhaesebroeck B, Stephens L and Hawkins P: PI3K signaling: The path to discovery and understanding. Nat Rev Mol Cell Biol 13: 195-203, 2012.

17. $\mathrm{Xu} \mathrm{K}$, Liu $\mathrm{P}$ and Wie W: mTOR signaling in tumorigenesis. Biochim Biophys Acta 1846: 638-654, 2014.

18. Cheong $\mathrm{H}$, Lindsten $\mathrm{T}, \mathrm{Wu} \mathrm{J}, \mathrm{Lu} \mathrm{C}$ and Thompson $\mathrm{CB}$ Ammonia-induced autophagy is independent of ULK1/ULK2 kinases. Proc Natl Acad Sci USA 108: 11121-11126, 2011.

19. Nash KM and Shah ZA: Current perspectives on the beneficial role of ginkgo biloba in neurological and cerebrovascular disorders. Integr Med Insights 10: 1-9, 2015.

20. Ni XW and Wu MC: Study on antitumor activities of ginkgolic acids from Ginkgo sarcotestas. J Huazhong Agricul Univ 4: 49-51, 2006.

21. Wang YF, Yang XM, Li YY, Li J, Huang BZ, Guo CY, Yi N and Xing $\mathrm{CH}$ : Inhibitory effect of ginkgols on SMMC-7721 liver cancer cells in vitro and liver cancer $\mathrm{H} 22$-bearing mice in vivo. J Jiangsu Univ 23: 233, 2013.

22. Chen Q, Yang GW and An LG: Apoptosis of hepatoma cells SMMC-7721 induced by Ginkgo biloba seed polysaccharide. World J Gastroenterol 8: 832-836, 2002.

23. Yang XM, Wang YF, Li YY and Ma HL: Thermal stability of ginkgolic acids from Ginkgo biloba and the effects of ginkgol C17:1 on the apoptosis and migration of SMMMC7721 cells. Fitoterapia 98: 66-76, 2014.

24. Liu J, Li Y, Yang X, Dong Y, Wu J and Chen M: Effects of ginkgol C17:1 on cisplatin-induced autophagy and apoptosis in HepG2 cells. Oncol Lett 15: 1021-1029, 2018
25. Yang XM, Zhang XL, Chen YC and Liu F: LC method for determination of ginkgolic acids in mice plasma and its application to pharmacokinetic study. Chromatographia 69: 593-596, 2009.

26. Fang YY, Yang XM, Li YY and Feng CL: Spectroscopic studies on the interaction of bovine serum albumin with Ginkgol C15:1 from Ginkgo biloba L. J Luminesceence 162: 203-211, 2015.

27. Li Y, Liu J, Yang X, Dong Y, Liu Y and Chen M: Ginkgol C17:1 inhibits tumor growth by blunting the EGF- PI3K/Akt signaling pathway. J Biomed Res 31: 232-239, 2017.

28. Ni HM, Bockus A, Wozniak AL, Jones K, Weinman S, Yin XM and Ding WX: Dissecting the dynamic turnover of GFP-LC3 in the autolysosome. Autophagy 7: 188-204, 2011.

29. Hu D, Wu J, Xu L, Zhang R and Chen L: A method for the establishment of a cell line with stable expression of the GFP-LC3 reporter protein. Mol Med Rep 6: 783-786, 2012.

30. Ndagi U, Mhlongo $\mathrm{N}$ and Soliman ME: Metal complexes in cancer therapy-an update from drug design perspective. Drug Des Devel Ther 11: 599-616, 2017.

31. Ziko L, Riad S, Amer M, Zdero R, Bougherara $\mathrm{H}$ and Amleh A: Mechanical stress promotes cisplatin-induced hepatocellular carcinoma cell death. Biomed Res Int 2015: 430569, 2015.

32. Cavallo F, Feldman DR and Barchi M: Revisiting DNA damage repair, p53-mediated apoptosis and cisplatin sensitivity in germ cell tumors. Int J Dev Biol 57: 273-280, 2013

33. Zhang HQ, He B, Fang N, Lu S, Liao YQ and Wan YY: Autophagy inhibition sensitizes cisplatin cytotoxicity in human gastric cancer cell line SGC7901. Asian Pac J Cancer Prev 14: 4685-4688, 2013

34. Li Y, Liu J, Liu Y, Yang X, Huang B and Chen M: Inhibitory effect of Ginkgol C17:1 on the biological behavior of tumor cells Oncol Lett 13: 1873-1879, 2017.

35. Wang $\mathbf{J}$ and $\mathrm{Wu}$ GS: Role of autophagy in cisplatin resistance in ovarian cancer cells. J Biol Chem 289: 17163-17173, 2014.

36. Yu L, Gu C, Zhong D, Shi L, Kong Y, Zhou Z and Liu S: Induction of autophagy counteracts the anticancer effect of cisplatin in human esophageal cancer cells with acquired drug resistance. Cancer Lett 355: 34-45, 2014

37. Xu Y, Yu H, Qin H, Kang J, Yu C, Zhong J, Su J, Li H and Sun L: Inhibition of autophagy enhances cisplatin cytotoxicity through endoplasmic reticulum stress in human cervical cancer cells. Cancer Lett 314: 232-243, 2012.

38. Yan MM, Ni JD, Song D, Ding M and Huang J: Interplay between unfolded protein response and autophagy promotes tumor drug resistance. Oncol Lett 10: 1959-1969, 2015.

39. Zhao J, Nie Y, Wang H and Lin Y: MiR-181a suppresses autophagy and sensitizes gastric cancer cells to cisplatin. Gene 576: 828-833, 2016.

40. Kondo Y, Kanzawa T, Sawaya R and Kondo S: The role of autophagy in cancer development and response to therapy. Nat Rev Cancer 5: 726-734, 2005.

41. Xie BS, Zhao HC, Yao SK, Zhou DX, Jin B, Lv DC, Wu CL, Ma DL, Gao C, Shu XM and Ai ZL: Autophagy inhibition enhances etoposide-induced cell death in human hepatoma G2 cells. Int J Mol Med 27: 599-606, 2011.

42. Shi SQ and Cao H: Shikonin promotes autophagy in BXPC-3 human pancreatic cancer cells through the PI3K/Akt signaling pathway. Oncol Lett 8: 1087-1089, 2014.

43. Sharma N, Nanta R, Sharma J, Gunewardena S, Singh KP, Shankar S and Srivastava RK: PI3K/AKT/mTOR and sonic hedgehog pathways cooperate together to inhibit human pancreatic cancer stem cell characteristics and tumor growth. Oncotarget 6: 32039-32060, 2015.

This work is licensed under a Creative Commons Attribution-NonCommercial-NoDerivatives 4.0 International (CC BY-NC-ND 4.0) License. 